Sains Malaysiana 50(1)(2021): 151-160

http://dx.doi.org/10.17576/jsm-2021-5001-15

\title{
Low-Energy Separation Technique on Purification of Unsaturated Fatty Acids of Palm Stearin using Methanol Crystallization Method
}

(Teknik Pemisahan Bertenaga Rendah bagi Penulenan Asid Lemak Tepu daripada Stearin Sawit Menggunakan Kaedah Pengkristalan Metanol)

FATimatuZZAhraA MOHD FADZEL, JUMAT SALIMON \& DARFIZZi DERAWI*

\begin{abstract}
This paper discussed the development of a low-energy and cost-effective separation technique of saturated fatty acids (SFAs) from Malaysian Palm Stearin to purify the unsaturation level of its fatty acids. Unsaturated fatty acids (UFAs) pose great benefits in nutritional value and also can be utilized as a raw material in various food or non-food applications. A methanol crystallization separation method was introduced by manipulating the storage temperature as well as the mixture ratio of palm stearin fatty acids (PSFAs) and methanol as a solvent. The separated compounds were characterized using Fourier-transform infrared (FTIR) spectroscopy, proton $\left({ }^{1} \mathrm{H}-\mathrm{NMR}\right)$, and carbon $\left({ }^{13} \mathrm{C}-\mathrm{NMR}\right)$ spectroscopy analysis techniques. The fatty acids composition for both UFAs and SFAs were determined through gas chromatography (GC) analysis technique. The highest separation yield was about 98\% (wt.), using a mixture of PSFA:methanol; 1:9 (w/v) at the temperature of $-20^{\circ} \mathrm{C}$. This method was successfully separated and purified the UFAs by increasing the unsaturation level of fatty acids about $172 \%$ as the final iodine value was about 98 compared to the initial value was at 36 . The low-energy methanol crystallization separation method is a cheaper method compared to the conventional high-energy fractional distillation process and positively to be up scaled at industrial level.
\end{abstract}

Keywords: Fatty acids; low-energy separation; methanol crystallization; palm stearin; separation technique

ABSTRAK

Kajian ini membincangkan pembangunan teknik pemisahan bertenaga rendah dan efektif kos asid lemak tepu (SFAs) daripada stearin sawit Malaysia untuk penulenan ketidaktepuan asid lemak stearin sawit. Asid lemak tak tepu (UFAs) mempunyai kelebihan nilai khasiat dan juga boleh digunakan sebagai bahan mentah dalam pelbagai aplikasi makanan dan bukan makanan. Suatu kaedah pemisahan pengkristalan metanol diperkenalkan dengan memanipulasikan suhu penyimpanan dan juga nisbah campuran asid lemak stearin sawit (PSFAs) dengan metanol sebagai pelarut. Sebatian yang terpisah akan dicirikan menggunakan teknik analisis spektroskopi transformasi Fourier inframerah (FTIR), spektroskopi proton $\left({ }^{1} H\right.$-NMR) dan karbon $\left({ }^{13} \mathrm{C}\right.$-NMR). Komposisi asid lemak bagi kedua-dua UFAs dan SFAs ditentukan menggunakan teknik analisis kromatografi gas (GC). Hasil pemisahan tertinggi adalah 98\% (wt.), menggunakan campuran PSFA: metanol; $1: 9$ (w/v) pada suhu $-20{ }^{\circ} \mathrm{C}$. Kaedah ini telah berjaya memisahkan dan menulenkan UFAs dengan meningkatkan tahap ketidaktepuan asid lemak sebanyak 172\% dengan nilai iodin akhir sebanyak 98 berbanding nilai awal sebanyak 36. Kaedah pemisahan pengkristalan metanol bertenaga rendah adalah lebih murah berbanding dengan proses pemisahan penyulingan berperingkat bertenaga tinggi dan positif untuk ditingkatkan pada skala industri.

Kata kunci: Asid lemak; pemisahan bertenaga rendah; pengkristalan metanol; stearin sawit, teknik pemisahan

\section{INTRODUCTION}

Palm oil is a major industrial crop product in tropical countries such as Malaysia, Indonesia, India, Africa, and Thailand (Mutsaers 2019). The crude oil derived from the fresh fruit bunches of the oil palm species E. guineensis (Maluin et al. 2020). It presents bright orange-red due to the high content of carotene (Laura 2017). Palm oil is semi-solid at room temperature. It contains about $50 \%$ of saturated compounds (Sue \& Pantzaris 2017). Palm oil and its products has excellent resistance to oxidation (Hashem et al. 2009) and heat at prolonged elevated temperatures (Khor et al. 2019); hence, making palm oil an ideal ingredient in frying oil blends (Dian et al. 2017). Besides, modified natural oils with high degree of unsaturation 
have improved frying stability compared to unmodified oils. On top of that, unsaturated fatty acids contribute to palm oil flavours and volatile compounds such as oleic acid, linoleic acid and linolenic acid (Azeman et al. 2015). Manufacturers and end-users around the world incorporate high percentages of palm oil in their frying oil blends for both performance and economic reasons (BuitimeaCantúa et al. 2017).

Today, 4.49 million hectares of land in Malaysia is under oil palm cultivation; producing 17.73 million tons of palm oil and 2.13 tons of palm kernel oil (Alam et al. 2015). Malaysia is one of the largest producers and exporters of palm oil in the world (Nambiappan et al. 2018), accounting for $11 \%$ of the world's oils \& fats production and $27 \%$ of export trade of oils \& fats. Palm oil also one of the highest contributors to Malaysians economic and industry activities (Azeman et al. 2015). The industry employs more than half a million people and livelihood to an estimated one million people (Sue \& Pantzaris 2009).

On the other hand, palm oil applications present a challenge in food and non-food applications due to its saturated fatty acids (SFAs) contents in triacylglycerols (TAGs) form (Omar et al. 2015). Palm stearin is the harder fraction of palm oil, containing a higher proportion of saturated fatty acids and TAGs with a higher melting point of $48-50{ }^{\circ} \mathrm{C}$ (Zhang et al. 2013). The palmitic acid content ranges from 49 to $68 \%$ and oleic content from 24 to 34\% (Omar et al. 2015). A much harder stearin containing $79 \%$ palmitic acid and a tripalmitoylglycerol (PPP) content of $60 \%$ is also available (Podchong et al. 2018). It is mainly used as hard stock for soft margarine and in infant fat formulas (Pande et al. 2012).

Even though renewable fatty acids are essential and highly demanded as starting materials in food and chemical industries (Salimon et al. 2011), but these SFAs might lower some physicochemical properties of the end products (Naghshineh et al. 2010). Therefore, the removal of saturated compounds from fatty acids content is essential to improve product quality (Karmakar et al. 2017; Rao et al. 2018). The olefin functional group with unsaturated fatty acids of vegetable oil can be performed by various reaction for few applications of edible and non-edible industry (Karmakar et al. 2017). Conventionally, the SFAs are separated and removed through a high-thermal fraction distillation process at the industrial scale. However, this process is a high-energy production process and higher cost of production. The invention of a cheaper method with simple production technology is getting more attention to reduce the production cost. One possible approach to remove the SFAs is through a straightforward and cheaper procedure is by performing a methanol crystallization separation technique. This method could be applied to separate SFAs effectively and increase the unsaturation level of fatty acids. Moreover, the methanol used in this procedure can be re-extracted at the end of the process and recyclable without reducing the quality of unsaturated fatty acids (UFAs) (Japir et al. 2018).

In this paper, the SFAs of Malaysian palm stearinbased fatty acids (PSFAs) were removed from the UFAs using a low-energy methanol crystallization separation method to increase and purified the unsaturated fatty acids. Preliminary characterization tests were employed to analyze the physicochemical properties of palm stearin. The final product composition was analyzed and characterized to evaluate the success of the employed separation method. The confirmation of initial and final products was performed using Fourier-transform infrared, gas chromatography and nuclear magnetic resonance analysis techniques.

\section{Materials AND Methods}

MATERIALS

Refined Bleached Deodorized Palm Stearin (RBDPS) was obtained from Jomalina Refinery, Sime Darby Plantation Sdn Bhd. KOH was prepared with 95\% ethanol. All chemicals purchased from Systerm and R\&M Chemicals and used without any pre-treatments.

\section{METHODS}

\section{PHYSICOCHEMICAL CHARACTERIZATIONS}

Preliminary physicochemical characterization tests will be performed to record the properties of RBDPS as raw materials. The characterization tests to be carried out such as iodine value, peroxide value, acid value, saponification, and unsaponifiable matter, slip melting point, pour point, flash point, kinematic viscosity, viscosity index, and thermal oxidative stability tests.

The iodine value for RBDPS, PSFA, SFA, and UFA were carried out by using Wijs method AOCS Cd1-25 to determine the unsaturation degree of samples (Salimon et al. 2006). The peroxide value is a measure of oxidation degree in a lipid sample and not the measurement of the lipid stability. It is also a measure of the formation of peroxide and hydroperoxide groups that are the initial products of the lipid oxidation. The peroxide value for RBDPS was carried out triplicates by using AOCS Cd853 method (Salimon et al. 2006). The acid value for RBDPS, PSFA, SFA, and UFA were carried out triplicates by using AOCS Cd3a-63 method (Salimon et al. 2006). The saponification value (BS 6842.6:1977) is the number of milligrams of potassium hydroxide $(\mathrm{KOH})$ required to saponify $1 \mathrm{~g}$ of fat under the conditions specified. The unsaponifiable matter was determined based on AOCS Ca 6a-40 (Salimon et al. 2006). The slip melting 
point was recorded based on AOCS Cc-1-25 (capillary) method (Salimon et al. 2006). The pour point of RBDPS was determined by ASTM D-97-17b (2016) with a slight modification using a U-tube as sample container. The U-tube was filled with sample and stored inside the freezer for overnight at the lowest temperature of $60{ }^{\circ} \mathrm{C}$. After overnight, the temperature will be observed for the sample started to flow and the temperature were recorded. This test was done in triplicates (Salimon et al. 2006). The flash point test for RBDPS was carried out based on ASTM D 92-05a method (2010). Kinematic viscosity was measured at 40 and $100{ }^{\circ} \mathrm{C}$ by using Anton Paar Physica MCR 301 Rheometer (Derawi \& Salimon 2013). The viscosity index is measured using ASTM D2270-10 (2016) by using the kinematic viscosity value at the temperature of 40 and $100{ }^{\circ} \mathrm{C}$. The oxidative stability test for RBDPS was carried out by using Pressured Differential Scanning Calorimetry (PDSC), Model DSC Q20. $3 \pm 0.2 \mathrm{mg}$ sample to be tested was introduced into PDSC and heated at 50-300 ${ }^{\circ} \mathrm{C}$ by using nitrogen gas at the rate of $10{ }^{\circ} \mathrm{C} / \mathrm{min}$ (Oleik 2013). Pressure introduced was 14 psi. The oxidative stability was observed at onset temperature. This test was carried out in triplicates (Jones 2015).

\section{HYDROLYSIS OF PALM STEARIN}

PSFAs were produced via hydrolysis of RBDPS. A series of optimization of hydrolysis was performed in order to form PSFA as final product. In this study, $50.0 \mathrm{~g}$ of RBDPS was heated upon stirring with the presence of $300 \mathrm{~mL}$ of $1.50,1.75$ and $2.00 \mathrm{M}$ ethanolic potassium hydroxide $(\mathrm{KOH})$. The condition for this reaction is by heating the mixture of RBDPS and ethanolic $\mathrm{KOH}$ at 70 , 75 , and $80^{\circ} \mathrm{C}$ for $2 \mathrm{~h}$. After $2 \mathrm{~h}, 6 \mathrm{~N}$ hydrochloric acid $(\mathrm{HCl})$ was added into the mixture to produce PSFA (Pavia et al. 2005). Purification was done by using $n$-hexane and distilled water (Kumar et al. 2017). The mixture was then left in sodium sulphate, $\mathrm{Na}_{2} \mathrm{SO}_{4}$ for $24 \mathrm{~h}$ to remove moisture. Unwanted solvent was eliminated by using rotary evaporator.

\section{METHANOL CRYSTALLIZATION METHOD}

The separation process of UFAs and SFAs used methanol as recoverable extraction solvent with some manipulated parameters. The methanol crystallization was previously studied by Japir et al. (2018) with different raw material and parameters. A series of the study carried out whereby the methanol was used to dissolve and extract the UFAs. Some predefined sets of experiments (PSFAs:methanol ratio: $1: 5,1: 6,1: 7,1: 8,1: 9$, and $1: 10)$ are stored at temperature of $-5,-10$, and $-20^{\circ} \mathrm{C}$ for $24 \mathrm{~h}$. After $24 \mathrm{~h}$, two layers of fatty acids will be formed where the bottom layer supposed to be the SFAs, and the top layer was the extracted
UFAs with methanol. Then, the solidified mixture was filtered with borosilicate glass filter funnel connected to a vacuum pump to speed up the filtration uniformly. The solid SFAs are rinsed using cold methanol to dissolve the remaining UFAs. The entire process was repeated three times by dissolving the SFAs and UFAs in methanol until the separation result has been completely ensured. The methanol was recovered from the extract using a rotary evaporator. Both UFAs and SFAs were dried in a vacuum oven at $45^{\circ} \mathrm{C}$ for $24 \mathrm{~h}$ to give final products.

\section{CHEMICAL FUNCTIONAL GROUP ANALYSIS}

The presence of functional groups in PSFAs, SFAs, and UFAs were confirmed through the Fourier-transform infrared (FTIR) spectroscopy analysis technique. Sample was prepared with $\mathrm{NaCl}$ plate for liquid samples whereas $\mathrm{KBr}$ pellet was used for solid samples. A thin film was covered on $\mathrm{NaCl}$ cells (Salimon et al. 2011). IR spectra were recorded in the range of 4000 to $700 \mathrm{~cm}^{-1}$. The FTIR utilized in this work is Perkin Elmer model (Salimon et al. 2006).

\section{FATTY ACID COMPOSITION}

Fatty acid compounds for all PSFAs, UFAs, and SFAs samples were analyzed through gas chromatography analysis technique, model BPX70 $(30 \mathrm{~m} \times 0.25 \mathrm{~mm} \times$ $0.25 \mu \mathrm{m})$ column. The injector and detector were set at 250 and $280^{\circ} \mathrm{C}$, respectively. The initial oven temperature was set at $280{ }^{\circ} \mathrm{C}$. The rate is $0.3 \mathrm{~mL} / \mathrm{min}$ and nitrogen gas was used as the carrier (Salimon et al. 2006).

\section{PROTON AND CARBON ANALYSIS}

The molecular structures of PSFAs, SFAs, and UFAs were confirmed through proton and carbon nuclear magnetic resonance $\left({ }^{1} \mathrm{H}-\mathrm{NMR}\right.$ and $\left.{ }^{13} \mathrm{C}-\mathrm{NMR}\right)$ spectroscopy analysis techniques. Both analyses determined the presence of proton and carbon in the sample (Tahari et al. 2015). Samples in the NMR tube will be diluted with deuterated chloroform $\left(\mathrm{CDCl}_{3}\right)$, then they were placed in between the magnet poles probe and radiate with energy (Pavia et al. 2009). The spectrometer is operating at 400.13 and 100.77 MHz (Salimon et al. 2006).

\section{RESULTS AND DISCUSSION}

\section{PHYSICOCHEMICAL PROPERTIES}

The physicochemical properties of RBDPS are tabulated in Table 1 in comparison to this study and the studies reported by Buitimea-Cantúa et al. (2017) and Malaysian Standard Specification: Palm Stearin (2007). Pour point, flash point and oxidative stability for RBDPS 
recorded were 37,190 , and $190{ }^{\circ} \mathrm{C}$, respectively. Pour point recorded is significantly high. This is due to the properties of PSFAs. Both branching and unsaturation in the fatty acid have the potential of reducing pour point. In comparison, unsaturated fatty acids are more effective in reducing pour point (Eastwood et al. 2005). PSFAs exist as a solid at room temperature and require temperature that is above room temperature in order to flow. Flash point and oxidative stability were recorded at the same temperature, which have been reported in the previous study (Fadzel et al. 2019). Thus, the tendency of PSFAs to form a flammable mixture with air is similar to the oxidative stability temperature.

TABLE 1. Physicochemical properties of palm stearin

\begin{tabular}{ccc}
\hline Physicochemical properties & Experimental & Reference* \\
\hline Iodine value & 36 & $27.8-45.1^{\mathrm{a}}$ \\
Peroxide value $\left(\right.$ meq $\mathrm{O}_{2} / \mathrm{kg}$ oil) & 0.3 & $0.2^{\mathrm{b}}$ \\
Acid value $(\mathrm{mgKOH} / \mathrm{g})$ & 0.3 & $0.25^{\mathrm{a}}$ \\
Saponification value & 191 & $193-205^{\mathrm{a}}$ \\
Unsaponifiable matter & 0.4 & $0.3-0.9^{\mathrm{a}}$ \\
Slip melting point $\left({ }^{\circ} \mathrm{C}\right)$ & 47 & $34^{\mathrm{a}}$ \\
Pour point $\left({ }^{\circ} \mathrm{C}\right)$ & 38 & $197^{\mathrm{b}}$ \\
Flash point $\left({ }^{\circ} \mathrm{C}\right)$ & 190 & $300^{\mathrm{b}}$ \\
Kinematic viscosity, $40{ }^{\circ} \mathrm{C}(\mathrm{cSt})$ & 300 & $10^{\mathrm{b}}$ \\
Kinematic viscosity, $100^{\circ} \mathrm{C}(\mathrm{cSt})$ & 10 & $-2^{\mathrm{b}}$ \\
Viscosity index & 190 & $190^{\mathrm{b}}$
\end{tabular}

*source: ${ }^{a}$ Malaysian Standard Specification: Palm Stearin (2007); 'buitimea-Cantúa 2017

\section{SEPARATION OF UFAS AND SFAS}

About 96\% (wt.) of PSFAs were produced from RBDPS via hydrolysis at $75{ }^{\circ} \mathrm{C}$ and $\mathrm{KOH}$ concentration of 1.75 M. PSFAs are majorly consist of $66 \%$ (wt.) of palmitic acid. The initial iodine value of PSFAs was 36 . The methanol crystallization process was successfully performed and separated both UFAs and SFAs. Figure 1 shows the correlation of PSFAs:methanol and percentage of yield at the temperatures of $-5,-10$ and $-20{ }^{\circ} \mathrm{C}$. The maximum yield was $98 \% \mathrm{w} / \mathrm{w}$ with mixture ratio of PSFAs: methanol; $1: 9(\mathrm{w} / \mathrm{v})$ at the temperature of $-20{ }^{\circ} \mathrm{C}$. The final iodine value (IV) observed for SFAs and UFAs were 0 and 98 , respectively. Based on the increasing of iodine value in UFAs, the conducted separation process has proven separating the saturated compounds and purify unsaturated fatty acids. The unsaturation level of fatty acid is high in the separation method by using methanol however depending on the high solubility degree of fatty acids in methanol (Japir et al. 2018). Monounsaturated and polyunsaturated fatty acids are more polar than that of saturated fatty acids. The polarity increases from linolenic acid to oleic acid (Jumaah et al. 2019). Therefore, unsaturated fatty acid is more soluble in methanol according to the principle of 'like dissolve like' and resulting in a high unsaturation level produced in this study. 


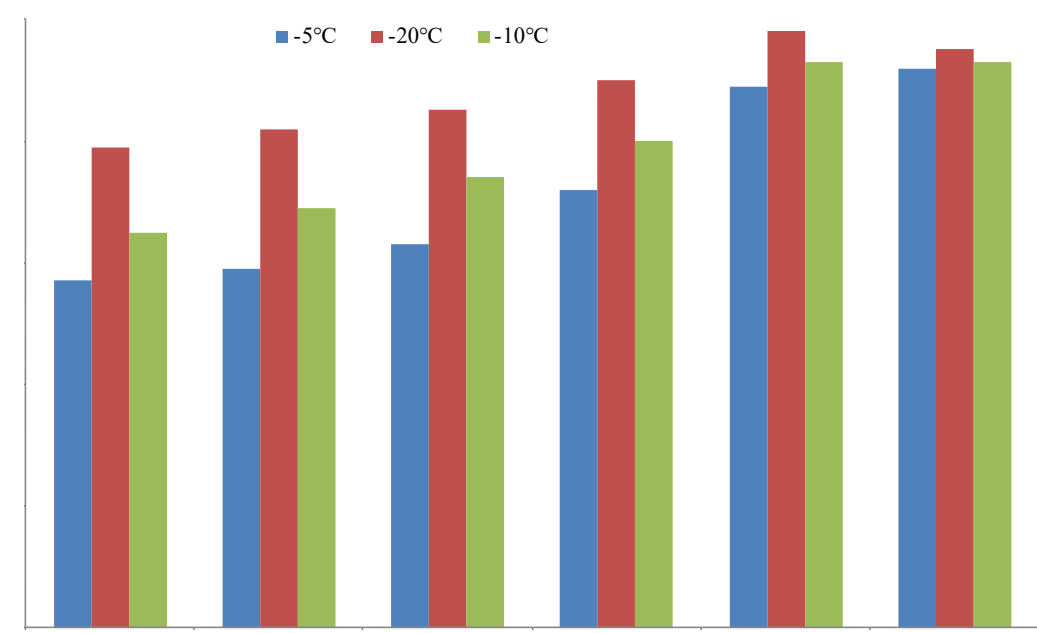

FIGURE 1. Ratio of PSFAs: methanol (wt/v) and the percent yield at temperatures of $-5,-10$ and $-20{ }^{\circ} \mathrm{C}$

\section{FTIR SPECTRA}

According to Figure 2, the $\mathrm{sp}^{3} \mathrm{CH}$ peaks are at 2926, 2856 $\mathrm{cm}^{-1}$ and a strong $\mathrm{C}=\mathrm{O}$ stretch band was observed at the region of $1705 \mathrm{~cm}^{-1}$ showing the presence of $\mathrm{COOH}$ group of fatty acid. Fatty acid was successfully produced during the hydrolysis of RBDPS as the bands shift from $1741 \mathrm{~cm}^{-1}$ (RBDPS) to $1705 \mathrm{~cm}^{-1}$ (PSFAs) as shown in Figure 2 . The separation of fatty acid has successfully produced SFAs and UFAs. It shows the absence of $\mathrm{C}=\mathrm{C}$ in SFAs (Figure 2) due to its properties which is saturated fatty acids and consist only single bonds, C-C. While the peak of UFAs is obviously shown at $3009 \mathrm{~cm}^{-1}$ due to the presence of $\mathrm{C}=\mathrm{C}$ bonds in UFAs. The $\mathrm{sp}^{3} \mathrm{CH}$ peaks are at 2926 and $2856 \mathrm{~cm}^{-1}$. The $\mathrm{C}=\mathrm{O}$ stretch peaks of both SFAs and UFAs show a strong band at 1696 and 1710 $\mathrm{cm}^{-1}$, respectively.

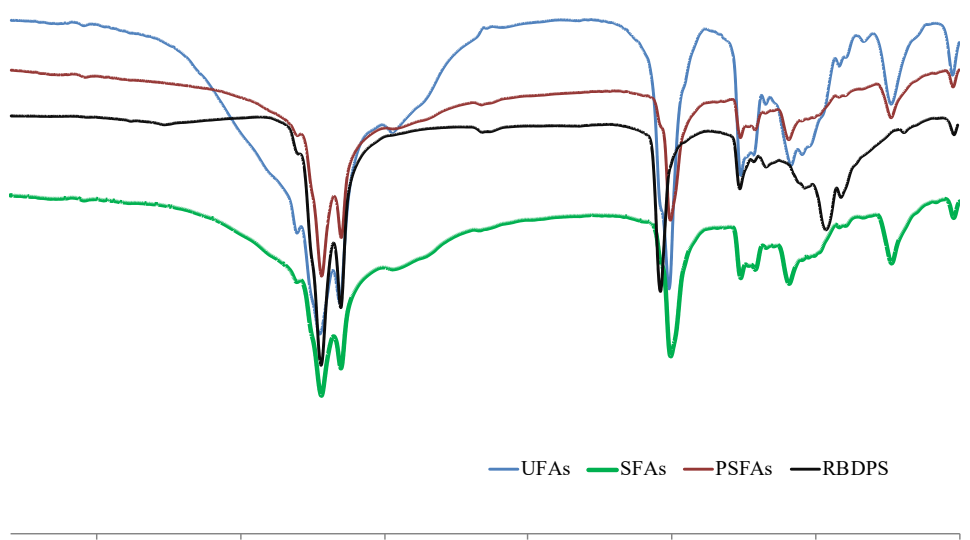

FIGURE 2. FTIR spectra for RBDPS, PSFAs, SFAs and UFAs 


\section{FATTY ACIDS COMPOSITION}

The fatty acids compositions of PSFAs, SFAs, and UFAs were showed in Figures 3, 4 and 5. The percentage compositions of methyl esters from respective chromatograms represent the fatty acids composition for each sample. Based on Figure 3, PSFAs was majorly consisted of palmitic acid $(63.2 \%)$, followed by oleic acid $(26.8 \%)$, linolenic acid (4.3\%), myristic acid $(3.8 \%)$, and stearic acid (1.7\%). After separation process was performed, the separated product which is UFAs was confirmed to have almost $99.9 \%$ of unsaturated compounds; mono-unsaturated oleic acid (C18:1) about $79.9 \%$ followed by $20 \%$ of poly-unsaturated linoleic acid (C18:2) (Figure 4). On the other hand, it can be seen that on the chromatogram of SFAs (Figure 5), almost all of the saturated fatty acids (palmitic acid: $92.2 \%$ and stearic acid: $7.8 \%$ ) have been observed in the postseparation residue sample. Based on comparison of these chromatograms, the unsaturated fatty acids of extracted compounds have been increased from $31.2 \%$ to $99.7 \%$, while the saturated compound has been removed totally to give high-purity UFAs product. The unsaturation degree of the final product, UFAs has been increased as its iodine value was increased from 36 to 98 . While, the residue SFAs was totally isolated as its iodine value was about 0 . So that, it has been confirmed that all the saturated compounds have been successfully isolated from the unsaturated compounds which is UFAs as the final product through the methanol crystallization process.

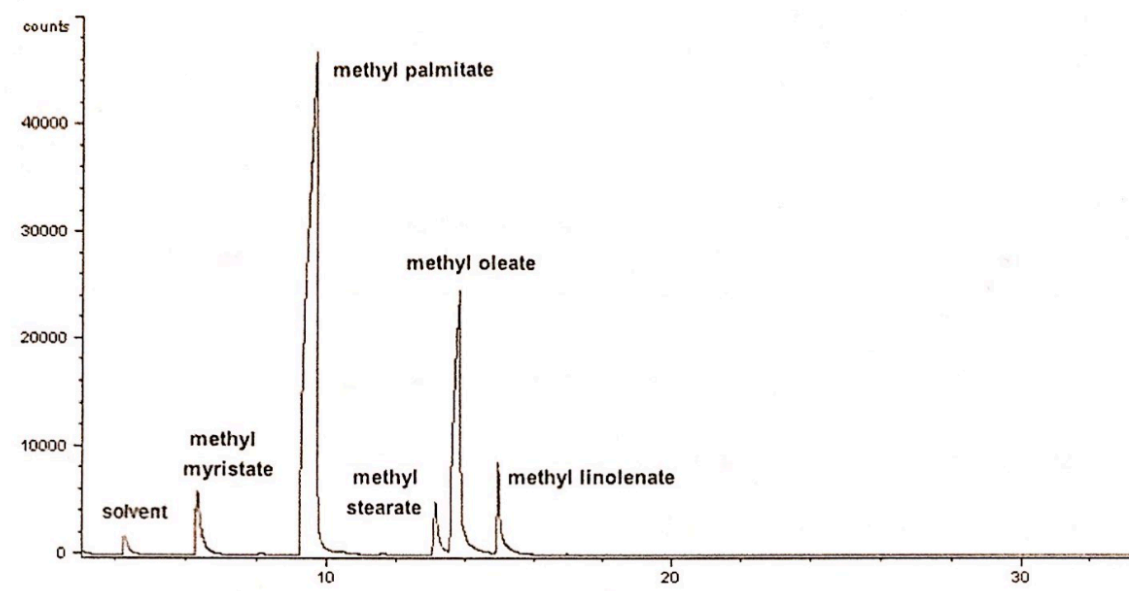

FIGURE 3. GC-FID Chromatogram of PSFAs

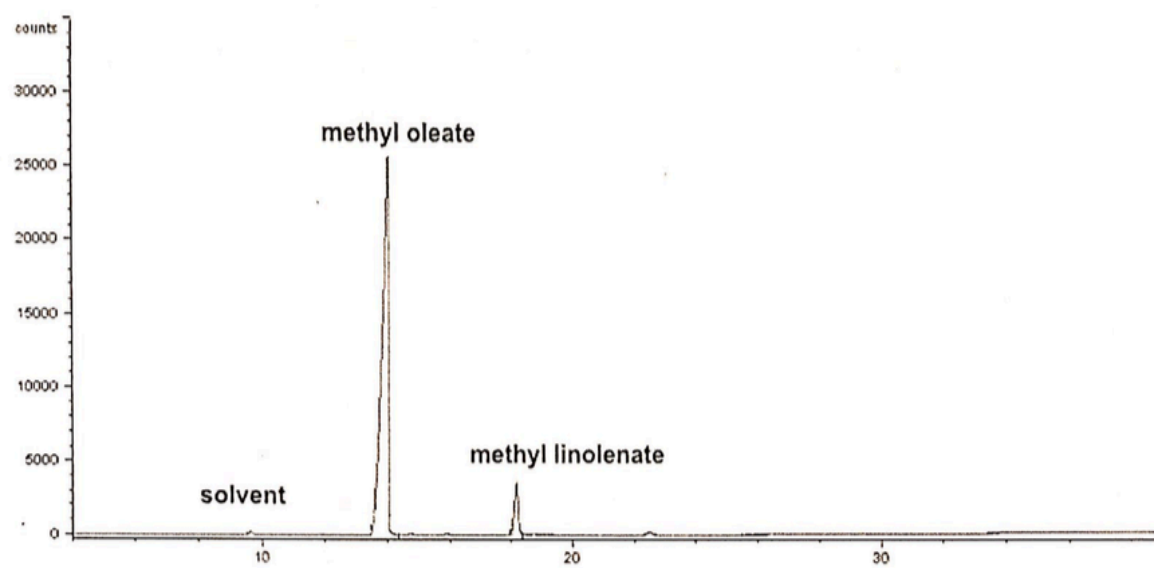

FIGURE 4. GC-FID Chromatogram of UFAs 


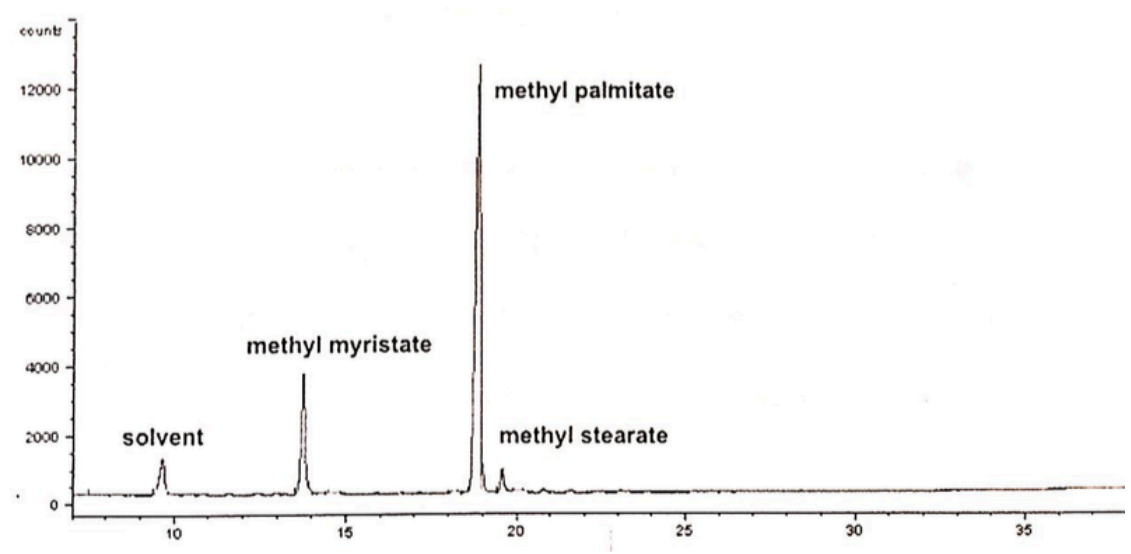

FIGURE 5. GC-FID Chromatogram of SFAs

The essential factor which determines the separation process using methanol crystallization method is the polarity of extraction solvent used in this experiment. UFAs contain of one or more carbon double bonds which are slightly polar to make them easily extracted by introducing methanol to the mixtures. While, SFAs are non-polar compounds and stay remain as residue at the bottom layer. Almost all of the unsaturated compounds can be extracted and purified through the performed methanol crystallization method. This method was proven enough to increase the UFAs of PSFAs from 31.2 to $99.7 \%$ of purity (Table 3 ). Besides, the recovered methanol as the extraction solvent is recyclable for the next separation process.

TABLE 3. The comparison of fatty acids composition before and after the methanol crystallization method

\begin{tabular}{cccc}
\hline Fatty acids (\%) & $\begin{array}{c}\text { Palm stearin } \\
\text { (or PSFAs) }\end{array}$ & Palm stearin $^{\mathrm{a}}$ & After separation (UFAs) \\
\hline Lauric acid; C12:0 & 1.20 & - & 0.00 \\
Myristic acid; C14:0 & 3.84 & 1.83 & 0.09 \\
Palmitic acid; C16:0 & 63.21 & 55.33 & 0.01 \\
Stearic acid; C18:0 & 0.31 & 9.72 & 26.0 \\
Oleic acid; C18:1 & 26.81 & 22.84 & 4.16 \\
Linoleic acid; C18:2 & 4.31 & 8.75 & 0.3 \\
Saturated & Rel $(\%)$ & 67.9 & 99.7 \\
Unsaturated $_{\text {Rel }}(\%)$ & 68.8 & 32.1 & 98 \\
Iodine value $^{2}$ & 31.2 & 32 & 9 \\
\hline
\end{tabular}

a source: Buitimea-Cantúa 2017 


\section{PROTON AND CARBON SPECTRA}

The comparisons of proton and carbon spectra of UFAs, SFAs, and PSFAs have been observed as in Figures 6 and 7. Proton and carbon analyses are essential for confirmation of unsaturated profile of extracted product (UFAs) compared to that of the residue (SFAs). The ${ }^{1} \mathrm{H}-\mathrm{NMR}$ spectrum in Figure 6(c) shows important signals of initial compounds, PSFAs that are R-COOH at $11.23 \mathrm{ppm}$ and triplet signal of $\mathrm{CH}-\mathrm{COOH}$ at 2.38-2.35 ppm (Zhang et al. 2013) have proven the existence of $\mathrm{COOH}$ attached to the fatty acid chain. The multiple signals of $\mathrm{CH}_{2}$ and $\mathrm{CH}_{3}$ in the long chain of PSFA were shown at 2.30-1.28 and $0.90-0.88 \mathrm{ppm}$, respectively. Chemical shift for the proton which attached to the unsaturated carbon, $\underline{\mathrm{HC}}=\mathrm{C} \underline{\mathrm{H}}$ was observed at $5.36 \mathrm{ppm}$ as represented by the hydrogen attached to $\mathrm{C}=\mathrm{C}$ referring to linoleic acid $(\mathrm{C} 18: 1)$; the second highest percentage after palmitic acid (C16:0). Whereas, ${ }^{13} \mathrm{C}$-NMR spectrum in Figure 7 (c) shows that carbon is attached to the carboxylic acid group at 173.45 ppm and double bond $\mathrm{C}=\mathrm{C}$ at $130.11-127.87 \mathrm{ppm} . \mathrm{CH}_{2}$ and $\mathrm{CH}_{3}$ signals were shown at 34.34-22.69 and 14.22-14.10 ppm, respectively.

UFAs and SFAs can be distinguished by looking at the unsaturated carbon profile for the ${ }^{1} \mathrm{H} /{ }^{13} \mathrm{C}$-NMR spectra. The ${ }^{1} \mathrm{H}-\mathrm{NMR}$ spectra in Figure 6(a) and 6(b) shows the chemical shifts of $\mathrm{CH}_{2}$ and $\mathrm{CH}_{3}$ for both SFA and UFA at $0.92-0.88,2.38-1.27$ and $2.79-1.29,0.91-0.89 \mathrm{ppm}$, respectively. Proton which is attached to the unsaturated carbon of UFAs, $\mathrm{HC}=\mathrm{CH}$ was observed at $5.36 \mathrm{ppm}$ in Figure 6(a) and related signal of the carbon attached to the double bond. The $\mathrm{C}=\mathrm{C}$ of UFAs was observed with a chemical shift at 130.20-127.90 ppm as shown by Figure 7(a). While, none chemical shift was detected on the same region in Figures 6(b) and Figure 7(b) and this indicates that SFAs consist of only saturated carbon compounds. Thus, these observations provide strong evidence that all unsaturated fatty acids have been successfully extracted from a mixture of saturated compounds (Japir et al. 2018).

(a) UFAs

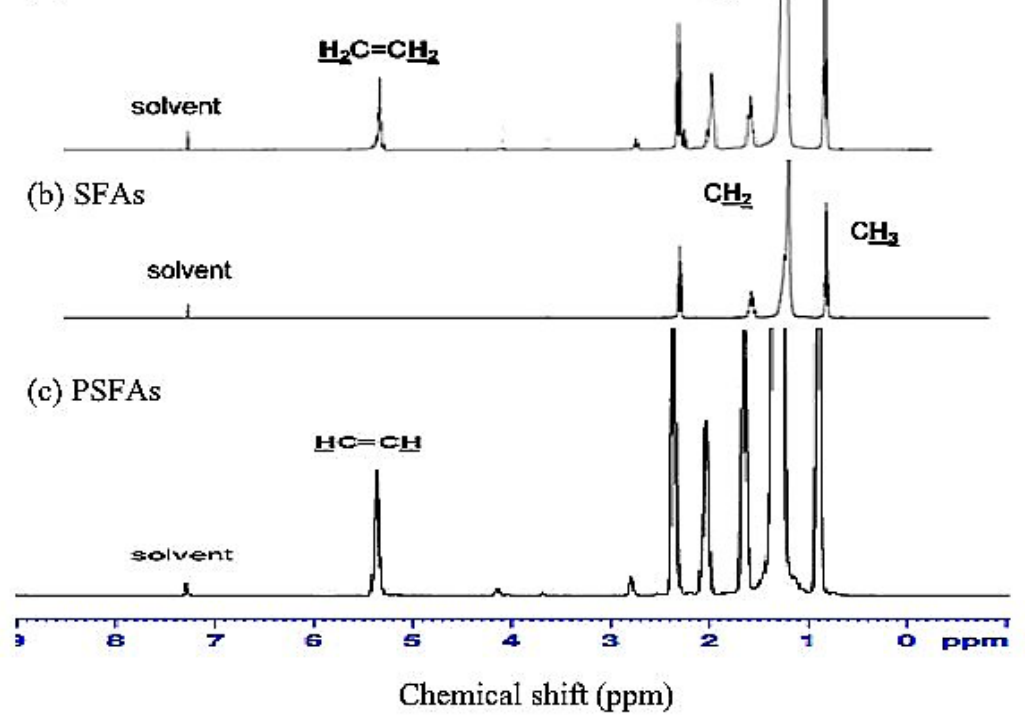

FIGURE 6. Comparison of ${ }^{1} \mathrm{H}-\mathrm{NMR}$ Spectra between (a) UFAs, (b) SFAs, and (c) PSFAs 


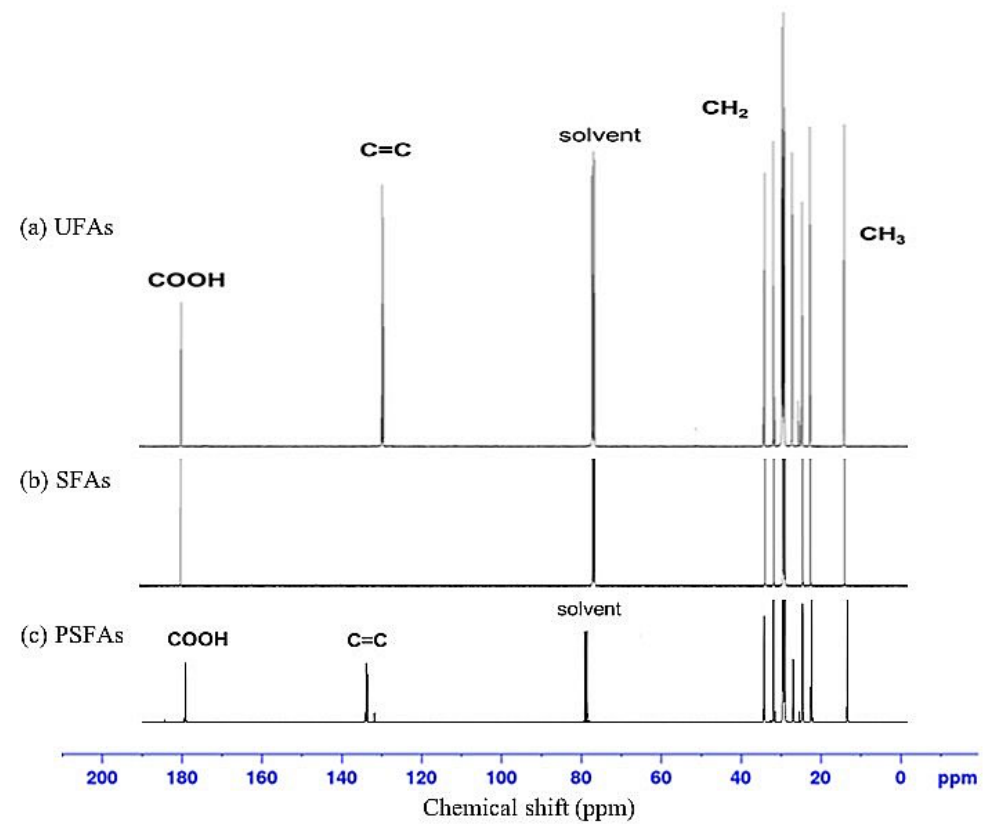

FIGURE 7. Comparison of ${ }^{13} \mathrm{C}-\mathrm{NMR}$ spectra between (a) UFAs, (b) SFAs, and (c) PSFAs

\section{CONCLUSION}

The development of a cheaper method for the extraction and purification of unsaturated fatty acids is crucial to make it sounds commercial-able at an upscaled process in the industry. This work was successfully established as a low-energy separation method. The methanol crystallization method was successfully purified up to $99.7 \%$ of UFAs compositions with a yield of $98 \%$ (wt.) using PSFA: methanol ratio of 1:9. The iodine value of the final product was increased by $172 \%$ (IV from 36 to 98 ). High purity UFAs are very valuable in the food and nonfood applications, particularly for the pharmaceutical and healthcare products.

\section{ACKNOWLEDGEMENTS}

The authors are grateful for the research facilities and financial support through the research grant GUP-2017-008 provided by Universiti Kebangsaan Malaysia. Authors would also like to express their condolences to all victims of COVID-19 and thank all frontliners for their continued support and commitment.

\section{REFERENCES}

Alam, A.F., Er, A.C. \& Begum, H. 2015. Malaysian oil palm industry: Prospect and problem. Journal of Food, Agriculture \& Environment 13(2): 143-148.
ASTM D97-17b. 2016. Standard Test Method for Pour Point of Petroleum Products. ASTM International, West Conshohocken, PA.

ASTM D2270-10. 2016. Standard Practice for Calculating Viscosity Index from Kinematic Viscosity at $40^{\circ} \mathrm{C}$ and $100^{\circ} \mathrm{C}$. ASTM International, West Conshohocken, PA.

ASTM D92-05a. 2010. Standard Test Method for Flash and Fire Points by Cleveland Open Cup Tester, ASTM International, West Conshohocken, PA.

Azeman, N.H., Yusof, N.A. \& Othman, A.I. 2015. Detection of free fatty acid in crude palm oil. Asian Journal of Chemistry 27(5): 1569-1573.

Buitimea-Cantúa, N.E., Salazar-García, M.G., Vidal-Quintanar, R.L., Serna-Saldívar, S.O., Ortega-Ramirez, R. \& BuitimeaCantúa, G.V. 2017. Formulation of zero-trans crystalized fats produced from palm stearin and high oleic safflower oil blends. Journal of Food Quality 2017: Article ID. 1253976.

Derawi, D. \& Salimon, J. 2013. Palm olein based biolubricant basesticks: Synthesis, characterization, tribological and rheological analysis. The Malaysian Journal of Analytical Sciences 17(1): 153-163.

Dian, N.L.H.M., Hamid, R.A., Kanagaratnam, S., Isa, W.R.A., Hassim, N.A.M., Ismail, N.H. \& Sahri, M.M. 2017. Palm oil and palm kernel oil: Versatile ingredients for food applications. Journal of Oil Palm Research 29(4): 487-511.

Eastwood, J., Swallow, A. \& Colmery, S. 2005. Selection criteria of esters in environmentally acceptable hydraulic fluids NCFP I05-4.2. In Proceedings of the National Conference on Fluid Power. Las Vegas, Nevada, USA. p. 107. 
Fadzel, F.M., Salimon, J. \& Derawi, D. 2019. Biolubricant production from palm stearin fatty acids and pentaerythritol. Malaysian Journal of Chemistry 21(2): 50-63.

Hashem, H.A., Shahat, M., El-Behairy, S.A \& Sabry, A. 2017. Use of palm olein for improving the quality properties and oxidative stability of some vegetable oils during frying process. Middle East Journal Applied Sciences 7(1): 68-79.

Japir, A.A.W., Salimon, J., Derawi, D., Yahaya, B.H., Bahadi, M., Al-Shuja'a, S. \& Yusop, M.R. 2018. A highly efficient separation and physicochemical characteristics of saturated fatty acids from crude palm oil fatty acids mixture using methanol crystallisation method. Oilseeds \& Fats Crops and Lipids 25(2): 1-8.

Jones, K. 2015. Zengshe Liu and George Kraus (eds): Green materials from plant oils. Chromatographia 78: 1315.

Jumaah, M.A., Yusoff, M.F.M., Salimon, J. \& Bahadi, M. 2019. Separation of saturated and unsaturated fatty acids of palm fatty acid distilled via low-temperature methanol crystallization. Malaysian Journal of Chemistry 21(2): 8-16.

Karmakar, G., Ghosh, P. \& Sharma, B.K. 2017. Chemically modifying vegetable oils to prepare green lubricants. Lubricants 5(4): 44.

Khor, Y.P., Hew, K.S., Abas, F., Lai, O.M., Cheong, L.Z., Nehdi, I.A., Sbihi, H.M., Gewik, M.M. \& Tan, C.P. 2019. Oxidation and polymerization of triacylglycerols: In-depth investigations towards the impact of heating profiles. Foods 8(10): 475.

Kumar, S.P.J., Prasad, S.R., Banerjee, R., Agarwal, D.K., Kulkarni, K.S. \& Ramesh, K.V. 2017. Green solvents and technologies for oil extraction from oilseeds. Chemistry Central Journal 11(1): 1-9.

Laura, C. 2017. Your Global Fats and Oils Connection. American Oil Chemist's Society. Malaysian Palm Oil Board.

Malaysian Standard-Palm Stearin Specification (2nd ed.):MS815:2007. Department of Standards Malaysia.

Maluin, F.N., Hussein, M.Z. \& Idris, A.S. 2020. An overview of the oil palm industry: Challenges and some emerging opportunities for nanotechnology development. Agronomy 10(3): 356.

Mutsaers, H.J.W. 2019. The challenge of the oil palm: Using degraded land for its cultivation. Outlook on Agriculture 48(3): 190-197.

Naghshineh, M., Ariffin, A.A., Ghazali, H.M., Mirhosseini, H. \& Mohammad, A.S. 2010. Effect of saturated/unsaturated fatty acid ratio on physicochemical properties of palm olein-olive oil blend. Journal of the American Oil Chemists Society 87(3): 255-262.

Nambiappan, B., Ismail, A., Hashim, N., Ismail, N., Shahari, D.N., Idris, N.A.N., Omar, N., Saleh, K.M., Hassan, N.A.M. \& Kushairi, A. 2018. Malaysia: 100 years of resilient palm oil economic performance. Journal of Oil Palm Research 30(1): 13-25.
Omar, Z., Hishamuddin, E., Sahri, M.M., Fauzi, S.H.M. Dian, N.L.H.M., Ramli, M.R. \& Rashid, N.A. 2015. Palm oil crystallization: A review. Journal of Oil Palm Research 27(2): 97-106.

Pande, G., Akoh, C.C. \& Lai, O.M. 2012. Food uses of palm oil and its components. In Palm Oil: Production, Processing, Characterization and Uses. Urbana Illinois: AOCS Press. pp. 561-586.

Pavia, D.L., Lampman, G.M., Kriz, G.S. \& Vyvyan, J.A. 2009. Introduction to Spectroscopy. Belmont, CA, USA: Brooks/ Cole-Thomson Learning.

Pavia, D.L., Lampman, G.M., Kriz, G.S. \& Engel, R.G. 2005. Introduction to Organic Laboratory Techniques: A Small Scale Approach. Belmont: Brooks/Cole-Thomson Learning.

Podchong, P., Tan, C.P., Sonwai, S. \& Rousseau, D. 2018. Composition and crystallization behavior of solventfractionated palm stearin. International Journal of Food Properties 21(1): 496-509.

Rao, T.V.V.L.N., Rani, A.M.A., Awang, M., Baharom, M. \& Uemura, Y. 2018. An overview of research on biolubricants in Malaysia and Japan for tribological applications. Jurnal Tribologi 18: 40-57.

Salih, N., Salimon, J. \& Yousif, E. 2013. The effect of chemical structure on pour point, oxidative stability and tribological properties of oleic acid triester derivatives. The Malaysian Journal of Analytical Sciences 17(1): 119-128.

Salimon, J., Abdullah, B.M. \& Salih, N. 2011. Hydrolysis optimization and characterization study of preparing fatty acids from Jatropha curcas seed oil. Chemistry Central Journal 5(1): 67.

Salimon, J., Said, M., Ramli, S. \& Lazim, M.A. 2006. Oils and Fats Analysis. Bangi: Universiti Kebangsaan Malaysia.

Sue, T.T. \& Pantzaris, T. 2009. Pocketbook of Oil Palm Uses. Kuala Lumpur: Malaysian Palm Oil Board.

Tahari, M.N.A., Samidin, S., Yarmo, M.A., Salih, N. \& Salimon, J. 2015. Synthesis and physicochemical studies of suberates as biolubricant basetock. Malaysian Journal of Analytical Sciences 19(1): 118-128.

Zhang, X., Li, L., Xie, H., Liang, Z., Su, J., Liu, G. \& Li, B. 2013. Comparative analysis of thermal behavior, isothermal crystallization kinetics and polymorphism of palm oil fractions. Molecules 18(1): 1036-1052.

Laboratory for Biolubricant, Biofuels and Bioenergy Department of Chemical Sciences

Faculty of Science and Technology

Universiti Kebangsaan Malaysia

43600 UKM Bangi, Selangor Darul Ehsan

Malaysia

*Corresponding author; email: darfizzi@ukm.edu.my

Received: 10 May 2020

Accepted: 24 June 2020 